\title{
Perbedaan Gender dalam Pengetahuan, Sikap dan Perilaku Mahasiswa Pendidikan Fisika
}

\author{
Syarif Barnas $^{1 *}$, Irwan Muhammad Ridwan ${ }^{1}$ \\ ${ }^{1}$ Program Studi Pendidikan Fisika, Universitas Siliwangi, Tasikmalaya, Indonesia \\ *e-mail korespondensi: Syarifbarnas@gmail.com
}

(masuk: 19-12-2019; revisi: 25-12-2019; diterima:31-12-2019)

\begin{abstract}
Abstrak: Dalam proses pendidikan, lingkungan mempunyai pengaruh yang cukup besar dalam pembentukan tingkah laku mahasiswa. Perguruan Tinggi sebagai tempat berlangsungnya proses pendidikan, situasi dan kondisinya akan turut menentukan dalam mempengaruhi pembentukan sikap dan perilaku mahasiswa. Cara dan kebiasaan hidup antara mahasiswa satu dengan mahasiswa lainnya tentu berbeda. Mahasiswa yang berjenis kelamin laki-laki memiliki perbedaan tertentu dengan mahasiswa yang berjenis kelamin wanita. Penelitian ini menggunakan metode deskriptif yang sifatnya kausal komparatif. Sampel dalam penelitian ini adalah mahasiswa Pendidikan Fisika FKIP Universitas Siliwangi angkatan 2018/2019. Metode pengumpulan data dengan tes, kuesioner dan wawancara. Sebelum diberi perlakuan terlebih dahulu dilakukan uji normalitas, uji kesamaan dua varian, dan uji keseimbangan. Hasil penelitian menunjukan bahwa mahasiswa perempuan lebih baik dalam hal pengetahuan dibandingkan dengan mahasiswa laki-laki, hal tersebut dapat dilihat dari rata-rata yang diperoleh tingkat pengetahuan mahasiswa laki-laki yaitu 19,11 dan mahasiswa perempuan sebesar 20,30. sikap terhadap pemeliharaan kebersihan lingkungan menunjukan bahwa mahasiswa perempuan lebih baik dari laki-laki dengan rata-rata skor untuk laki-laki 107,10 dan perempuan 108,20. Untuk perilaku dalam memelihara kebersihan lingkungan di kampus, mahasiswa perempuan lebih baik dibanding dengan mahasiswa laki-laki dengan nilai rata-rata skor mahasiswa laki-laki adalah sebesar 79,72 dan skor rata-rata mahasiswa perempuan adalah 82,70 .
\end{abstract}

Kata kunci: Gender, Pengetahuan, Sikap, Perilaku

\section{Pendahuluan}

Dalam proses pendidikan, lingkungan mempunyai pengaruh yang cukup besar dalam pembentukan tingkah laku mahasiswa. Perguruan Tinggi sebagai tempat berlangsungnya proses pendidikan, situasi dan kondisinya akan turut menentukan dalam mempengaruhi pembentukan sikap dan perilaku mahasiswa. Karena Perguruan Tinggi sebagai lembaga yang melaksanakan tugas mendidik maupun mengajar, serta memperbaiki, memproses tingkah laku peserta didik yang dibawa dari lingkungan keluarganya.

Untuk mencapai pemahaman dan kesadaran seperti di atas memang tidak mudah, salah satunya berkaitan dengan jenis kelamin yang akan menentukan cara atau kebiasaan hidup. Cara dan kebiasaan hidup ini berbeda antara mahasiswa satu dengan mahasiswa lainnya. Mahasiswa yang berjenis kelamin laki-laki memiliki perbedaan tertentu dengan mahasiswa yang berjenis kelamin wanita.

$$
\text { Jans dalam Monk }
$$

mengemukakan bahwa sejak permulaan ada perbedaan pada dua jenis kelamin apa yang mungkin dapat disebut matriks kondisioning yang permulaan. Mengenai hal ini mungkin dapat dianggap adanya suatu dasar biologis yang memungkinkan dua jenis kelamin tadi mengembangkan tingkah laku yang berbeda-beda. Dari 
sudut pandangan biologis tampaknya dapat diterima bahwa ada perbedaan disposisional yang menyebabkan pelajaran tingkah laku yang berbeda antara mahasiswa laki-laki dengan mahasiswa perempuan sehingga akan mempengaruhi juga terhadap sikap, perilaku mahasiswa di Perguruan Tinggi. Perguruan Tinggi sebagai pelayan masyarakat dalam proses pendidikan, merupakan tempat belajar mahasiswa, dalam proses pendidikan ini lingkungan mempunyai pengaruh yang cukup besar dalam pembentukan tingkah laku mahasiswa.

Dengan melihat adanya perbedaan secara biologis antara mahasiswa laki-laki dengan mahasiswa perempuan yang akan mempengaruhi perubahan tingkah laku sebagai cara dan kebiasaan hidup antara mahasiswa laki-laki dengan mahasiswa perempuan berbeda maka penulis dalam penelitian ini ingin mengetahui adakah perbedaan antara mahasiswa laki-laki dengan mahasiswa perempuan dalam hal pengetahuan, sikap dan perilaku.

\section{Metode Penelitian}

Metode yang digunakan dalam penelitian ini adalah metode deskriptif yang sifatnya kausal komparatif. Dipilihnya metode deskriptif didasarkan alasan bahwa dalam penelitian ini membandingkan satu faktor dengan faktor yang lain. (Winarno Surakhmad, 1982 : 143).

Desain penelitian yang diajukan dapat dilihat pada gambar sebagai berikut:

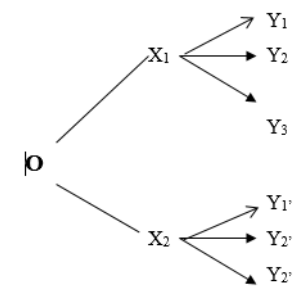

Gambar 1. Desain Penelitian

Keterangan :

$\mathrm{O}=$ Sampel penelitian

$\mathrm{X}_{1}=$ mahasiswa laki-laki

$\mathrm{X}_{2}=$ mahasiswa perempuan

$\mathrm{Y}_{1}=$ tingkat pengetahuan mahasiswa

$\mathrm{Y}_{2}=$ sikap mahasiswa.

$\mathrm{Y}_{3}=$ perilaku mahasiswa.
Teknik pengumpulan data yang digunakan oleh peneliti adalah angket atau kuesioner untuk mendapatkan data tentang sikap dan perilaku mahasiswa. Sedangkan untuk memperoleh data hasil pengetahuan mahasiswa dilakukan dengan menggunakan data skunder, yaitu Indeks Prestasi Kumulatif (IPK).

Kuesioner 'Sikap Mahasiswa' berjumlah 25 pernyataan. Alternatif jawabannya ada lima pilihan. Skor untuk setiap pernyataan berbeda-beda. Jika pernyataan positif maka skor yang diberikan untuk setiap alternatif jawaban adalah : Sangat Setuju (SS) $=5$, Setuju (S) $=4$, Ragu-ragu $(\mathrm{R})=3$, Tidak Setuju (TS) $=2$, Sangat Tidak Setuju $($ STS $)=1$. Akan tetapi jika pernyataan negatif maka skor yang diberikan untuk setiap alternatif jawaban adalah : Sangat Setuju $(\mathrm{SS})=1$, Setuju $(\mathrm{S})=2$, Ragu-ragu $(\mathrm{R})=3$, Tidak Setuju $(\mathrm{TS})=4$, Sangat Tidak Setuju $(\mathrm{STS})=5$.

Untuk menjaring kedua jenis data yang diperlukan sebagaimana telah disebutkan terdahulu, disusun tiga jenis instrumen sebagai berikut :

1) Instrumen A, yaitu seperangkat butir test yang dimaksudkan untuk mengukur sikap terhadap pemeliharaan kebersihan lingkungan kampus, dan;

2) Instrumen B yaitu seperangkat butir test yang dimaksudkan untuk mengukur perilaku dalam pemeliharaan kebersihan lingkungan kampus.

Untuk menganalisis data yang diperoleh dalam penelitian ini menggunakan uji normalitas dan uji homogenitas. Sedangkan uji hipotesis menggunakan uji beda dengan uji t.

Penelitian dilaksanakan di Jurusan Pendidikan Fisika Fakultas Keguruan dan Ilmu Pendidikan Universitas Siliwangi.

\section{Hasil dan Pembahasan}

Hasil pengolahan data dari responden sebanyak 22 orang mahasiswa laki-laki dan 46 mahasiswa perempuan menunjukkan bahwa rentangan skor untuk tingkat pengetahuan mahasiswa 
laki-laki, berkisar antara 2,23 sampai dengan 3,60, dan simpangan bakunya sebesar 0,382. Skor tengah di atas berada di atas rata-rata, yang besarnya 3,08 dan ini dapat diartikan bahwa mahasiswa laki-laki di Program Studi Pendidikan Fisika memiliki tingkat pengetahuan pada kategori tinggi. Deskripsi umum dari data pengetahuan tentang kebersihan lingkungan Kampus, dapat dilihat pada Tabel 1.

Tabel 1. Pengetahuan mahasiswa laki-laki tentang kebersihan lingkungan di program studi Pendidikan Fisika

\begin{tabular}{cccc}
\hline Mean & SD & $\begin{array}{c}\text { Skor } \\
\text { Minimum }\end{array}$ & $\begin{array}{c}\text { Skor } \\
\text { Maksimum }\end{array}$ \\
\hline 3,08 & 0,382 & 2,23 & 3,60 \\
\hline
\end{tabular}

\section{Histogram dari data variabel pengetahuan tentang kebersihan lingkungan kampus dapat dalam Gambar 2 .}

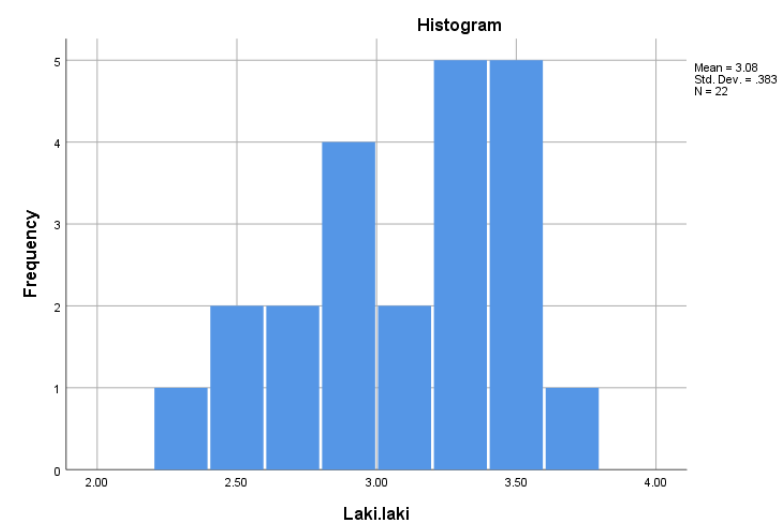

Gambar 2. Histogram Data Variabel Pengetahuan Mahasiswa Laki-laki

Hasil pengolahan data dari responden sebanyak 46 orang mahasiswa perempuan menunjukkan bahwa rentangan skor untuk tingkat pengetahuan mahasiswa perempuan, berkisar antara 1,33 sampai dengan 3,93 dan simpangan bakunya sebesar 0,421. Skor tengah di atas, berada di atas ratarata, yang besarnya 3,16 dan ini dapat diartikan bahwa para mahasiswa perempuan di Program Studi Pendidikan Fisika memiliki tingkat pengetahuan tentang kebersihan lingkungan kampus pada kategori tinggi. Deskripsi umum dari data pengetahuan perempuan tentang kebersihan lingkungan kampus, dapat dilihat pada Tabel 2 .

Tabel 2. Pengetahuan mahasiswa perempuan tentang kebersihan lingkungan

\begin{tabular}{cccc}
\hline Mean & SD & $\begin{array}{c}\text { Skor } \\
\text { Minimum }\end{array}$ & $\begin{array}{c}\text { Skor } \\
\text { Maksimum }\end{array}$ \\
\hline 3,16 & 0,421 & 1.33 & 3.33 \\
\hline
\end{tabular}

Histogram dari data variabel pengetahuan tentang kebersihan lingkungan kampus terdapat dalam Gambar 3.

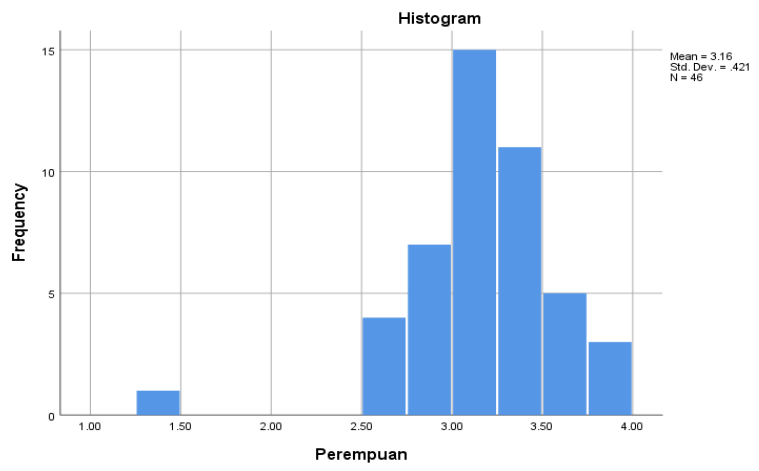

Gambar 3. Histogram Data Variabel Pengetahuan Mahasiswa Perempuan

Hasil pengolahan data dari responden sebanyak 22 orang mahasiswa laki-laki menunjukkan bahwa rentangan skor untuk sikap mahasiswa laki-laki terhadap pemeliharaan kebersihan lingkungan kampus, berkisar antara 60 sampai dengan 95, dan simpangan bakunya sebesar 10,320. Skor tengah di atas berada di atas rata-rata, yang besarnya 77,27 dan ini dapat diartikan bahwa para mahasiswa perempuan di Program Studi Pendidikan Fisika memiliki sikap pada kategori baik tentang kebersihan lingkungan kampus. Deskripsi umum dari data sikap laki-laki tentang kebersihan lingkungan kampus, dapat dilihat pada Tabel 3 .

Tabel 3. Variabel sikap mahasiswa lakilaki tentang kebersihan lingkungan

\begin{tabular}{cccc}
\hline Mean & SD & $\begin{array}{c}\text { Skor } \\
\text { Minimum }\end{array}$ & $\begin{array}{c}\text { Skor } \\
\text { Maksimum }\end{array}$ \\
\hline 77,27 & 10,32 & 60 & 95 \\
\hline
\end{tabular}




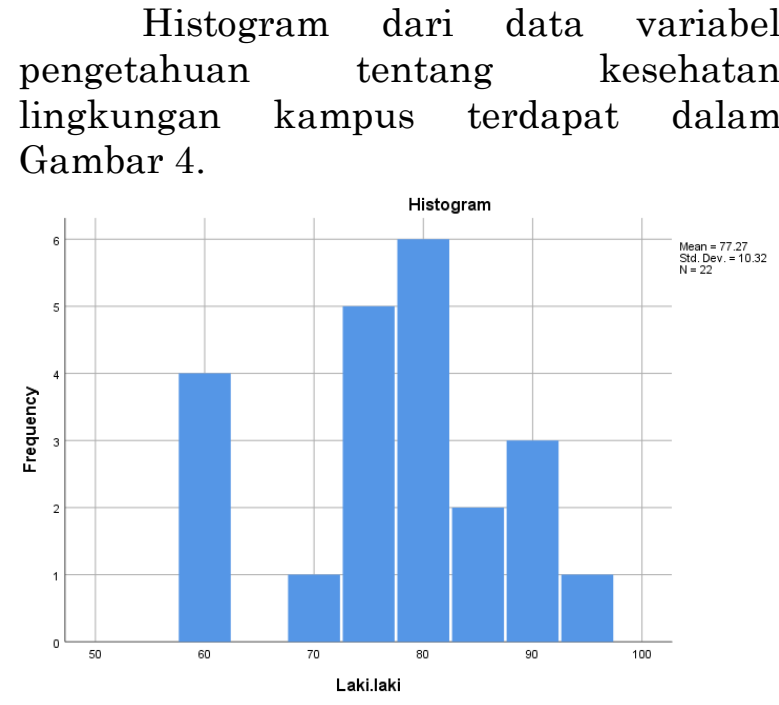

Gambar 4. Sikap mahasiswa laki-laki tentang kebersihan lingkungan kampus

Hasil pengolahan data dari responden sebanyak 46 orang menunjulkan bahwa sikap mahasiswa perempuan Program Studi Pendidikan Fisika dalam memelihara kebersihan lingkungan kampus menunjukkan bahwa rentangan skor untuk sikap mahasiswa perempuan, berkisar antara 60 sampai dengan 95, dan simpangan bakunya sebesar 9,900. Skor tengah di atas berada di atas rata-rata, yang besarnya 76,74 dan ini dapat diartikan bahwa para mahasiswa perempuan di Program Studi Pendidikan Fisika memiliki sikap pada pemeliharaan kebersihan lingkungan kampus pada kategori baik. Deskripsi umum dari data tentang sikap mahasiswa perempuan terhadap kebersihan lingkungan kampus, dapat dilihat pada Tabel 4.

Tabel 4. Sikap mahasiswa perempuan tentang kebersihan lingkungan

\begin{tabular}{cccc}
\hline Mean & SD & $\begin{array}{c}\text { Skor } \\
\text { Minimum }\end{array}$ & $\begin{array}{c}\text { Skor } \\
\text { Maksimum }\end{array}$ \\
\hline 76,94 & 9,900 & 60 & 95 \\
\hline
\end{tabular}

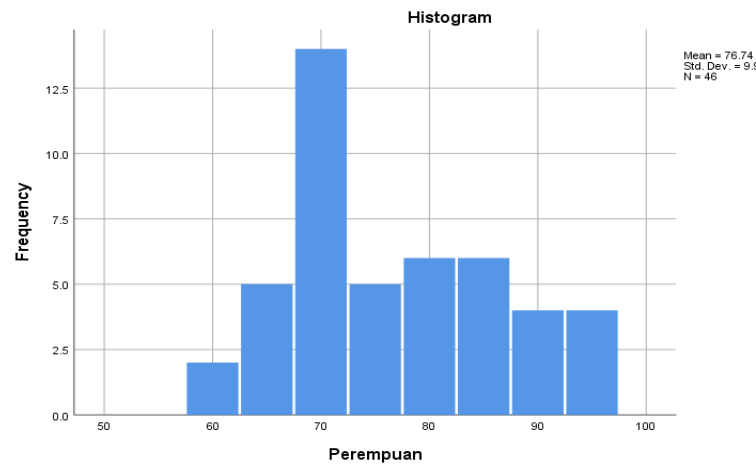

Gambar 5. Sikap mahasiswa perempuan tentang kebersihan lingkungan kampus

\section{Perilaku Mahasiswa Laki-laki}

Data yang diperoleh dari responden sebanyak 22 orang Mahasiswa laki-laki, menunjukkan bahwa rentangan skor untuk variabel perilaku Mahasiswa lakilaki, berkisar antara 50 sampai dengan 95, dan simpangan bakunya sebesar 11,991. Skor tengah di atas berada di atas ratarata, yang besarnya 76,59 dan ini dapat diartikan bahwa para Mahasiswa laki-laki di Program Studi Pendidikan Fisika memiliki perilaku pada kategori baik. Deskripsi umum dari data perilaku tentang kebersihan lingkungan Kampus, dapat dilihat pada tabel di bawah ini.

Tabel 5. Perilaku mahasiswa laki-laki tentang kebersihan lingkungan

\begin{tabular}{|c|c|c|c|}
\hline Mean & SD & $\begin{array}{c}\text { Skor } \\
\text { Minimum }\end{array}$ & $\begin{array}{c}\text { Skor } \\
\text { Maksimum }\end{array}$ \\
\hline 76,59 & 11,991 & 50 & 95 \\
\hline
\end{tabular}

Histogram dari data variabel pengetahuan tentang kebersihan lingkungan kampus terdapat dalam Gambar 6.

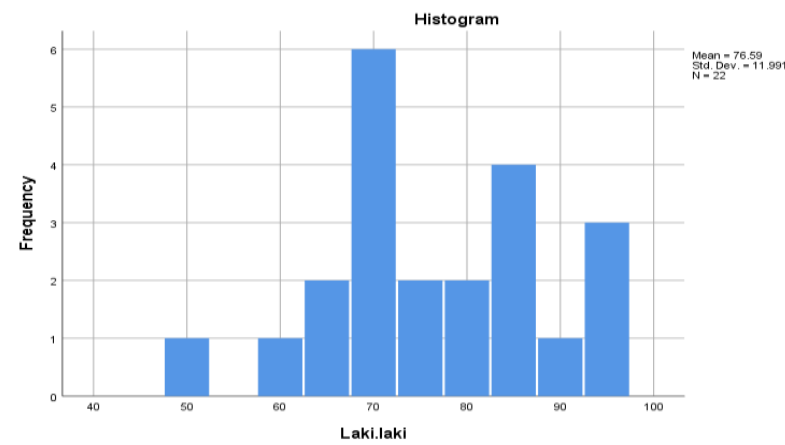

Gambar 6. Histogram data variabel perilaku mahasiswa laki-laki 


\section{Perilaku Mahasiswa Perempuan}

Data yang diperoleh dari responden sebanyak 46 orang mahasiswa perempuan menunjukkan bahwa rentangan skor untuk perilaku mahasiswa perempuan, berkisar antara 60 sampai dengan 90, dan simpangan bakunya sebesar 8,923. Skor tengah di atas, berada sama dengan ratarata, yang besarnya 77,17 dan ini dapat diartikan bahwa mahasiswa perempuan di Program Studi Pendidikan Fisika memiliki perilaku pengetahuan tentang kebersihan lingkungan kampus pada kategori baik. Deskripsi umum dari data perilaku perempuan tentang kebersihan lingkungan kampus, dapat dilihat pada Tabel 6.

Tabel 6. Perilaku mahasiswa perempuan tentang kebersihan

\begin{tabular}{cccc}
\hline Mean & SD & $\begin{array}{c}\text { Skor } \\
\text { Minimum }\end{array}$ & $\begin{array}{c}\text { Skor } \\
\text { Maksimum }\end{array}$ \\
77,17 & 8,923 & 60 & 90 \\
\hline
\end{tabular}

Histogram dari data variabel perilaku tentang kebersihan lingkungan kampus terdapat dalam Gambar 7 .

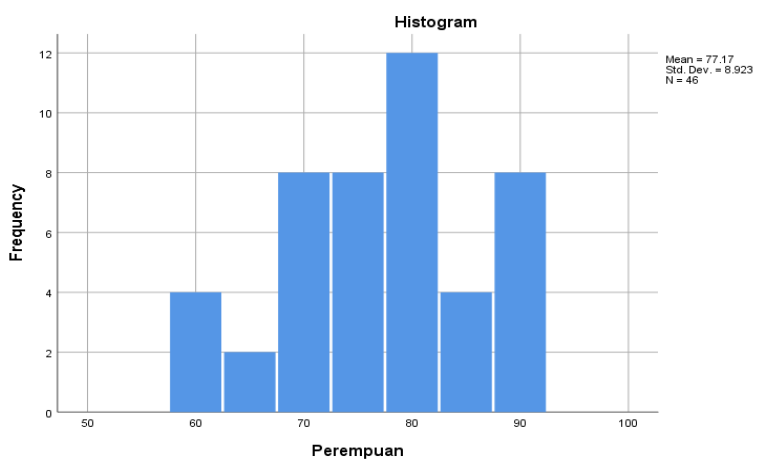

Gambar 7. Histogram data variabel perilaku mahasiswa perempuan

Berikut ini akan disajikan hasil pengujian terhadap hipotesis yang diajukan pada penelitian ini.

1. Perbedaan Tingkat Pengetahuan antara Mahasiswa Laki-laki dan Perempuan dalam Memelihara Kebersihan Lingkungan Di Program Studi Pendidikan Fisika

Hipotesis pertama dalam penelitian ini adalah terdapat perbedaan antara pengetahuan Mahasiswa laki-laki $\left(\mathrm{Y}_{1}\right)$ dengan pengetahuan Mahasiswa perempuan $\left(\mathrm{Y}_{1}{ }^{\prime}\right)$ di Program Studi Pendidikan Fisika dalam memelihara kebersihan lingkungan Kampus.

Pengolahan data untuk variabel tingkat pengetahuan seperti sudah dikemukakan pada bab terdahulu, menggunakan dummy variabel dengan alasan supaya keseluruhan jenis data menjadi sejenis.

Dari hasil analisis diperoleh untuk $a=5 \%$ diperoleh bahwa thitung $=2,256>$ $t_{0,95(84)}=2,378$, maka $\mathrm{H}_{0}$ ditolak dan $\mathrm{H}_{1}$ diterima. Artinya terdapat perbedaan antara tingkat pengetahuan Mahasiswa laki-laki dan perempuan dalam pemeliharaan kebersihan lingkungan Kampus di Program Studi Pendidikan Fisika.

2. Perbedaan antara sikap Mahasiswa Laki-laki dan Perempuan dalam Memelihara Kebersihan Lingkungan kampus

Hipotesis kedua yang diajukan dalam penelitian ini adalah terdapat perbedaan antara sikap Mahasiswa lakilaki $\left(\mathrm{Y}_{2}\right)$ dengan sikap perempuan $\left(\mathrm{Y}_{2^{\prime}}\right)$ di Program Studi Pendidikan Fisika dalam memelihara kebersihan lingkungan Kampus.

Dari hasil analisis uji perbedaan (uji - t) untuk $a=5 \%$ diperoleh bahwa $t_{\text {hitung }}=1,092>t_{0,95(84)}=0,878$, maka $\mathrm{H}_{0}$ ditolak dan $\mathrm{H}_{1}$ diterima. Artinya terdapat perbedaan antara tingkat pengetahuan Mahasiswa laki-laki dan perempuan dalam pemeliharaan kebersihan lingkungan Kampus di Program Studi Pendidikan Fisika.

3. Perbedaan antara Perilaku Laki-laki dengan Perempuan dalam Memelihara Kebersihan Lingkungan Kampus

Hipotesis ketiga yang diajukan dalam penelitian ini adalah terdapat perbedaan antara perilaku Mahasiswa laki-laki $\left(\mathrm{Y}_{3}\right)$ dengan perilaku perempuan ( $\mathrm{Y}_{3}$ ) dalam memelihara kebersihan lingkungan di Program Studi Pendidikan Fisika. 
Dari hasil analisis uji perbedaan (uji - t) untuk $a=5 \%$ diperoleh bahwa $t_{\text {hitung }}=1,092>t_{0,95(84)}=0,978$, maka $\mathrm{H}_{0}$ ditolak dan $\mathrm{H}_{1}$ diterima. Artinya terdapat perbedaan antara tingkat pengetahuan Mahasiswa laki-laki dan perempuan dalam pemeliharaan kebersihan lingkungan Kampus di Program Studi Pendidikan Fisika.

Penelitian tentang perbedaan antara Mahasiswa laki-laki dengan perempuan dalam pengetahuan, sikap dan perilaku dalam memelihara kebersihan lingkungan di Program Studi Pendidikan Fisika telah dilaksanakan oleh peneliti dengan berbagai persiapan yang matang. Pelaksanaan penelitian ini dimulai dengan perencanaan, mulai dari pembuatan instrumen-instrumen penelitian yang terdiri dari tes pengetahuan, kuesioner sikap dan perilaku untuk mengungkap adanya perbedaan dalam memelihara kebersihan lingkungan di Kampus. Kegiatan penelitian ini, dilanjutkan dengan melaksanakan observasi dengan tujuan untuk melakukan pemilihan sampel yang dilakukan secara acak (random). Selanjutnya penelitian dilanjutkan dengan melakukan kegiatan memberikan tes untuk tingkat pengetahuan dan kuesioner untuk mengukur sikap serta perilaku dalam memelihara kebersihan lingkungan kampus.

Berdasarkan hasil perolehan dan pengolahan data yang diuji melalui analisis statistik menggunakan SPSS seri 25.0, dapat diperoleh beberapa gambaran bahwa terdapat perbedaan antara tingkat pengetahuan Mahasiswa laki-laki dengan Mahasiswa perempuan di Program Studi Pendidikan Fisika dalam memelihara kebersihan lingkungan. Dan data menunjukkan bahwa mahasiswa perempuan lebih baik dalam memelihara kebersihan lingkungan kampus dibandingkan dengan Mahasiswa lakilaki, hal tersebut dapat dilihat dari ratarata yang diperoleh tingkat pengetahuan mahasiswa laki-laki yaitu 19,11 dan mahasiswa perempuan sebesar 20,30 dan masing-masing skor perolehan mahasiswa dapat dilihat dalam diagram batang sebagai berikut:

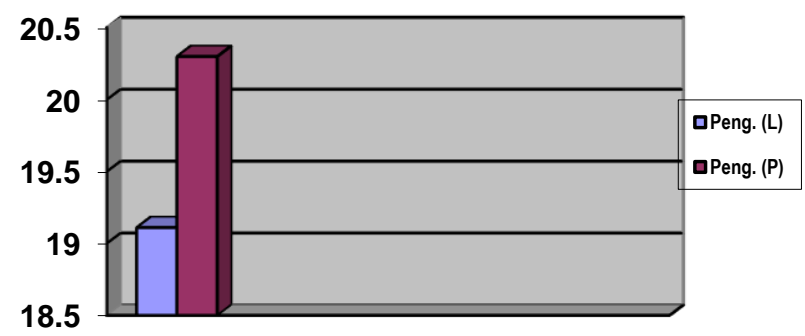

\section{Gambar 8. Grafik Skor Rata-rata \\ Pengetahuan Tentang Kebersihan Lingkungan}

Skor perolehan Mahasiswa lakilaki dan perempuan dalam bersikap terhadap pemeliharaan kebersihan lingkungan menunjukkan bahwa Mahasiswa perempuan lebih baik dari skor perolehan laki-laki, masing-masing memperoleh rata-rata, untuk laki-laki 108,20 dan skor untuk perempuan 107,10 dan masing-masing skor perolehan Mahasiswa dapat dilihat dalam diagram batang sebagai berikut:

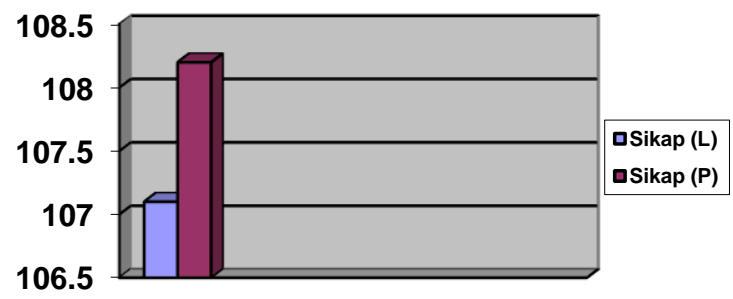

\section{Gambar 9. Skor Rata-rata Sikap Tentang Kebersihan Lingkungan}

Untuk skor perilaku dalam memelihara kebersihan lingkungan hidup di Kampus, diperoleh nilai rata-rata Mahasiswa laki-laki adalah sebesar 79,72. Sedangkan nilai rata-rata skor akhir yang diperoleh Mahasiswa perempuan adalah 82,70 . Pada variabel ini nilai rata-rata perempuan lebih baik dari nilai rata-rata laki-laki. Untuk lebih jelasnya dapat dilihat dalam Gambar 10. 


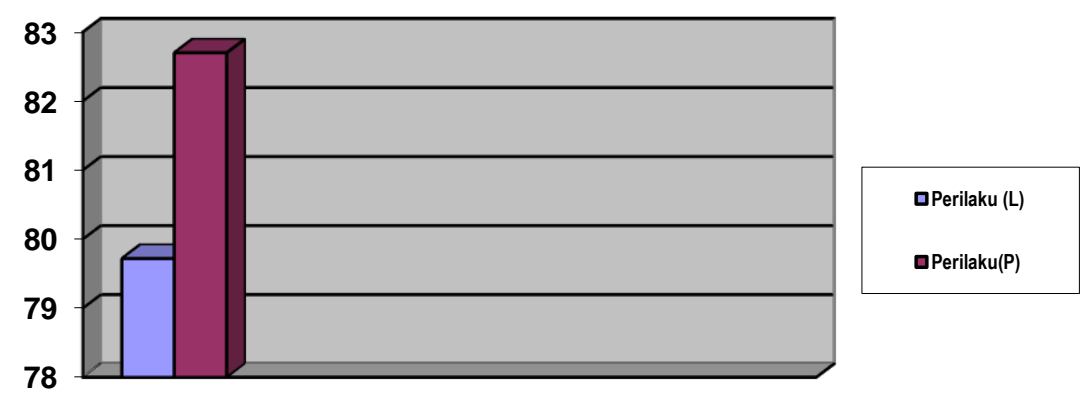

Gambar 10. Skor Rata-rata Perilaku Tentang Kebersihan Lingkungan

Berdasarkan hasil perolehan dan pengolahan data serta pengujian hipotesis, terlihat bahwa perbedaan antara Mahasiswa laki-laki dan Mahasiswa perempuan dalam tingkat pengetahuan, sikap maupun perilaku dalam memelihara lingkungan hanya menujukan perbedaan yang paralel dalam satu variabel saja dan tidak dapat digeneralisasikan atau disimpulkan bahwa ada perbedaan yang mutlak antara Mahasiswa laki-laki dan perempuan dalam ketiga variabel yang diteliti, hal ini dapat dilihat dari perbedaan rata-rata keseluruhan yang menunjukan ada variasi perbedaan dari ketiga variabel seperti ditunjukan pada Gambar 11.

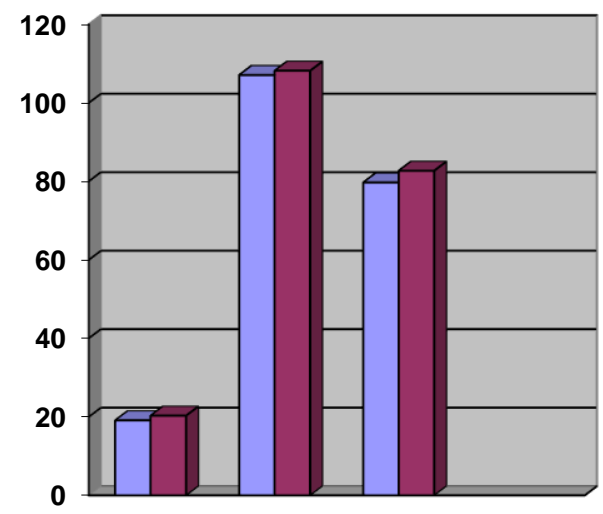

口Laki-laki aPerempuan

\section{Gambar 11. Skor Rata-rata Pengetahuan, Sikap dan Perilaku Tentang Pemeliharaan Kebersihan Lingkungan}

Perbedaan antara mahasiswa lakilaki dan perempuan dalam memelihara kebersihan lingkungan kampus pada ketiga variabel yang diteliti hanya menunjukkan perbedaan yang relatif diantara satu variabel saja dan tidak menujukan perbedaan secara umum. Perbedaan antara laki-laki dan perempuan memang ada hanya sebatas pada variabel-variabel tertentu. Hal tersebut sesuai dengan pendapat Jans dalam Monk (2002: 192) yang menyatakan bahwa ada perbedaan sejak permulaan pada dua jenis kelamin (matriks conditioning) yang dapat dianggap sebagai suatu dasar biologis yang memungkinkan dua jenis kelamin ini, mengembangkan tingkah lalu yang berbeda-beda. Monk (dalam Rahayu, 2002) menjelaskan bahwa ada 3 kriteria yang membedakan anak laki-laki dengan perempuan, yaitu dalam hal (1) kriteria pemasakan seksual, (2) permulaan pemasakan seksual, dam (3) urutan gejala-gejala pemasakan. Perbedaan tingkat pengetahuan, sikap, dan perilaku pada mahasiswa laki-laki 
dan mahasiswa perempuan dalam memelihara kebersihan lingkungan kampus dimungkinkan karena adanya perbedaan pada pemasakan seksual, permulaan pemasakan seksual dan gejala pemasakan.

Berdasarkan pengujian hipotesis menyimpulkan bahwa terdapat perbedaan pengetahuan, sikap dan perilaku antara mahasiswa laki-laki dengan mahasiswa perempuan dalam memelihara kebersihan lingkungan di Program Studi Pendidikan Fisika.

\section{Penutup}

Berdasarkan hasil penelitian yang diperoleh daat diambil kesimpulan sebagai berikut:

1. Hasil penelitian menunjukkan deskripsi umum tingkat pengetahuan laki-laki dan perempuan pada kategori tinggi dalam memelihara kebersihan lingkungan kampus.

2. Hasil penelitian dalam sikap mahasiswa laki-laki dan Perempuan memiliki sikap pada kategori baik tentang kebersihan lingkungan Kampus

3. Hasil penelitian mahasiswa laki-laki dan perempuan di Program Studi Pendidikan Fisika memiliki perilaku pada kategori baik dalam memelihara kebersihan lingkungan kampus.

\section{Referensi}

Abu Ahmadi. 1999. Teori dan Pengukuran Pengetahuan, Sikap, dan Perilaku. Yogyakarta: Nuhu Medika.

Ananta, Aris. 1993.Ciri Demografis Kualitas Penduduk Dalam Pembangunan Ekonomi. Lembaga Demografi.FEUI. Jakarta.

Ausubel, D.P. (1968). Educational Psychology: a Cognitive View. New York: Holt, Rinehart and Winston.

Cronbach. 1971. Introduction to Psychology, Sixth Edition, New York: Mc. Graw Hill International Book Company: Morgan.
Miftah Thoha (1990). Perilaku Organisasi, Konsep Dasar dan Aplikasinya. Rajawali Press, Jakarta

Moekijat. (1984). Dasar-Dasar Motivasi, Bandung : Sumur Bandung

Monks, F.J. Psikologi Perkembangan: Pengantar Dalam Berbagai Bagiannya. Cet. 14.: Yogyakarta: Gajah Mada University Press; 2002

Natawidjaja, Rochman, Fungsi dan Profesionalisasi Petugas Bimbingan dan Konseling dalam Pendidikan, Bandung : IKIP, 1990 Soekanto, Soerjono, Kamus Sosiologi, Jakarta: PT. Raja Grafindo Persada, 1993

Soekidjo Notoatmodjo. 1997. Pendidikan dan Perilaku Kesehatan dalam Ilmu

Kesehatan Masyarakat. Jakarta: Rineka Cipta.

Surakhmad, winarno. (1982). Pengantar Interaksi Belajar Mengajar, Dasar, dan Teknik Metodologi pengajaran. Bandung: Tarsito 